\title{
PHYSICAL-CHEMICAL PROPERTIES OF PESTICIDES: CONCEPTS, APPLICATIONS, AND INTERACTIONS WITH THE ENVIRONMENT
}

\author{
PROPRIEDADES FÍSICO-QUÍMICAS DOS AGROTÓXICOS: \\ CONCEITOS, APLICAÇÕES E INTERAÇÕES COM O AMBIENTE
}

\author{
Vanderley José PEREIRA ${ }^{1}$; João Paulo Arantes Rodrigues da CUNHA ${ }^{2}$; \\ Tâmara Prado de MORAIS ${ }^{3}$; João Paulo RIBEIRO-OLIVEIRA ${ }^{4}$; João Batista de MORAIS ${ }^{4}$ \\ 1. Doctoral student in Plant Production, Instituto de Ciências Agrárias - ICIAG, Universidade Federal de Uberlândia - UFU, Uberlândia, \\ MG, Brazil. vamceres.vanderley@gmail.com; 2. Professor, ICIAG - UFU, Uberlândia, MG, Brazil; 3. PhD in Plant Science, ICIAG - \\ UFU, Uberlândia, MG, Brazil; 4. PhD in Plant Production, ICIAG - UFU, Uberlândia, MG, Brazil; 5. Graduated in Chemistry, UFU, \\ Uberlândia, MG, Brazil.
}

\begin{abstract}
What are the molecular properties of agricultural chemicals, how do they function and why should they be studied? How do they affect the agroecosystem and how are they linked to application technologies? These questions arise due to the lack of information in the literature about this issue and form the basis of the current review. In general, a better understanding of the physical-chemical characteristics of agricultural chemicals makes it possible to improve their efficiency of application, consequently reducing losses and maintaining the integrity of the environment. These points underscore the importance of this subject, which has been deeply discussed in Europe. In Brazil, there are few studies that examine the physicochemical properties of pesticides at the molecular level and virtually none that examine their impact. Thus, the current study attempts to clarify the concepts, applications, and interactions of the physical-chemical properties of agricultural chemicals with the environment. The trade secrets associated with these molecules are essential to the agrochemical industry, which certainly restricts scientific publications on the topic. Nevertheless, these properties are linked to the products' mobility in the soil, disassociation in water, bioaccumulation, persistence, and durability in the environment and on the target. In summary, the more mobile and persistent a molecule is, the greater its potential for seepage and leaching and, consequently, the greater its potential for contaminating surface, subsurface, and ground water. This type of molecule becomes more environmentally aggressive if it bioaccumulates readily and degrades slowly. It should be noted that proper handling of agrochemicals depends not only on an understanding of their molecular properties, but also on their safe application. These concepts are essential for the successful promotion and sustainable use of these products in rural areas.
\end{abstract}

KEYWORDS: Agrochemicals. Molecular properties. Application technology. Sustainability.

\section{INTRODUCTION}

Optimization of agricultural output is usually associated with the use of agrochemicals. However, this assertion is weakened in the face of damage to the environment and plague's resistance to agrochemicals due to irresponsible use (PAULA et al., 2011). Thus, the market is in constant need of new molecules with different active ingredients and different modes of action. However, the physicalchemical characterization of these molecules is poorly covered in the literature (GEBLER; BELLO FIALHO, 2011). Consequently, initiatives that address these questions are needed.

The molecular structure of an agrochemical greatly determines its degree of interaction with the environment. For instance, functional groups containing oxygen, nitrogen, and sulfur tend to make organic compounds more chemically and biologically reactive and more soluble in water compared to less volatile hydrocarbons having the same carbon number. Halogens such as fluorine, chlorine, and bromine, on the other hand, make compounds less water-soluble, more volatile, typically less reactive, and thus more environmentally stable (SILVA; FAY, 2004; CABRERA et al., 2008).

Interactions of a substance with the soilplant-atmosphere system are quite complex and dependent on physical and chemical characteristics (CAPEL, 1993). The specificity and diversity of environments moreover, complicate studies and generate major inconsistencies in research results (BARRIGOSSI et al., 2005). In addition, few studies report the impact of these properties on applications or on the environment. In general, studies that have focused on physicochemical properties have investigated adjuvants and spray solutions, whereas few reports have focused on the agrochemical products themselves.

The intrinsic properties of these products are also related to application efficiency and 
consequently to application technology. In this regard, the spraying process, which converts a liquid into droplets, depends on the physicochemical properties of the spray solutions (PROKOP; KEJKLÍCEK, 2002; QUEIROZ et al., 2008). Thus, molecular analysis deserves equal scientific attention.

Few publications list the key features of current molecules (ALTENBURGER et al., 1993; SHEN; WANIA, 2005; GEBLER et al., 2006; MACKAY et al., 2006). These publications are treated as product selection guides since these properties are usually not printed on packages. However, this information can be requested from the manufacturer since product registrations require an ecotoxicological assessment report with a physicochemical characterization that must contain the: physical state, appearance, color and odor, molecular identification, purity, metallic impurities, melting and boiling point / range, $\mathrm{pH}$, dissociation constant, formation constant for metal complexes, density, surface tension of solutions, viscosity, particle distribution by size, corrosivity, thermal and room-temperature stability, flash point, and oxidizing properties (IBAMA, 2012). The results of these analyses are specific to each substance and agrochemical characterizations are defined by one or two of these properties. Due to the limited number of publications on the physical and chemical properties of agrochemicals, usually associated with trade secrets, one might ask: which, how, and why study these molecular properties? What are the impacts on the agroecosystem? How should these properties be linked to specific application technologies? These questions formed the basis of this literature review.

\section{Molecular and organoleptic properties}

Molecular descriptors are essential for product identification. Molar mass, molar volume, critical temperature, and molecular area are useful for specific purposes, especially when making mixtures. Organoleptic characteristics are also important because they are easy to see and stand out well in plant protection products (CABRERA et al., 2008) (Table 1). The physical state, aspect, color, and odor help in the identification of a product, especially after accidents where substance identification is not immediately possible (MINGUELA; CUNHA, 2011). Generally, substances of higher purity produce stronger characteristics. Nevertheless, pure products are difficult to produce and some metallic impurities such as chrome, arsenic, cadmium, mercury, and lead hinder identification by altering product properties and can, depending on concentration, adversely affect the environment. Product density is one of the most affected properties because the densities of metals are usually higher than those of other substances.

Table 1. Organoleptic characteristics of some plant protection products (Source: Farm Chemicals International, 2012).

\begin{tabular}{cc} 
2012). & Organoleptic characteristics \\
\hline Product & Almost white, odorless \\
Carbendazim & Amber colored solution, almost odorless or with a slight amine smell \\
Glyphosate (Roundup) & Crystalline powder, odorless, beige-brown \\
Cyproconazole & Gray granules, slight phenolic odor \\
2,4-D (Aqua-Kleen) & Yellow-orange crystals \\
Trifluralin & Opaque orange liquid, mild aromatic odor \\
Oryzalin (Surflan)
\end{tabular}

Density is the ratio of mass to volume at a specific temperature and is expressed as $\mathrm{kg} \mathrm{m}^{-3}$ in the International System of Units (SI) (MACKAY et al., 2006). Most organic compounds are less dense than water whereas halogenated organic compounds are more dense (CUNHA et al., 2010). Similar to density, water solubility, or miscibility, determines the fate of organic compounds in the soil.

\section{Physical-chemical properties related to mobility}

Solubility in water is defined as the maximum quantity of a molecule that can be dissolved in water (BARRIGOSSI et al., 2005; MARTINS et al., 2013). Generally, the more hydrophilic groups a substance possesses, the more polar a substance is and consequently the greater affinity the substance has for water; the more soluble a substance is, the greater tendency the substance has for transport through the environment (BARRIGOSSI et al., 2005; OLIVEIRA; BRIGHENTI, 2011; MARTINS et al., 2013). This last characteristic can be an environmental risk since it implies that an agrochemical could be transported through surface soil by rain or irrigation water and eventually reach surface water (BARRIGOSSI et al., 2005; OLIVEIRA; BRIGHENTI, 2011). Generally, products that are highly soluble in water are displaced to greater depths than less soluble 
products. Accordingly, compounds such as acephate, cartap, 2,4-D, glyphosate, methamidophos, methomyl, and paraquat are more likely to be removed from the soil (MILHOME et al., 2009). However, this single parameter cannot be used alone to predict percolation but should be evaluated with the soil-water partition.

The solubility of most chemical products is generally measured in $\mathrm{mg} \mathrm{L}^{-1}$ (or parts per million) at controlled $\mathrm{pH}$ and temperatures from 20 to $25^{\circ} \mathrm{C}$ (MACKAY et al., 2006). pH must be controlled since ionizable functional groups within the molecular structures may be protonated or deprotonated depending on the $\mathrm{pH}$ of the medium (MARTINS et al., 2013). Thus, at alkaline pH, molecules are ionized and therefore more soluble in polar solvents such as water. In contrast, molecules with low $\mathrm{pH}$ have a greater affinity for non-polar solvents such as octanol.

Chemicals with high water solubility are transported to greater depths. Highly soluble molecules tend to have relatively low adsorption coefficients and bioconcentration factors. Additionally, these products tend to biodegrade more rapidly in soil and in water (GEVAO et al., 2000; MACKAY et al., 2006).

Dissolved organic matter, such as humic acids and fulvic acids, increases the solubility of various agrochemicals due to partition with organic matter. Water solubility is a prerequisite for biodegradation and bioaccumulation tests; however, these should not be assessed individually since several other parameters should also be considered to better understand the fate of substances in the environment. Chemicals that are highly soluble in water tend to end up in aquatic systems; however, this cycle can be modified by several processes including sorption and evaporation. In general, agrochemicals with solubility above $30 \mathrm{ppm}$ may be subject to leaching and consequent groundwater contamination (Table 2).

Table 2. Agrochemical solubility in water (DIAS, 2010).

\begin{tabular}{ccc}
\hline Classification & Solubility category & $(\mathbf{p p m})$ \\
\hline 1 & Insoluble & $<1$ \\
2 & Very low & $1-10$ \\
3 & Low & $11-50$ \\
4 & Intermediate & $51-150$ \\
5 & High & $151-500$ \\
6 & Very high & $500-5000$ \\
7 & Extremely high & $>5000$ \\
\hline
\end{tabular}

Solubility is of paramount importance to efficient application of agrochemicals. In general, chemigated soluble fungicides can be washed away by foliar irrigation and end up on the soil, reducing their protective benefits. This effect is minimized by systemic fungicides that are absorbed by leaves and/or roots (BRIGGS et al., 1982). Conversely, fungicides that are poorly soluble in water but soluble in oil are encapsulated in droplets that do not lose integrity in water (MINGUELA; CUNHA, 2011). These authors also warned that, dissimilar to chemigation, solubility becomes less important in conventional applications due to the smaller amounts of water used. Lower water quantities also reduce potential runoff. Generally, protective fungicides are poorly soluble in water. Systemic fungicides conversely are soluble in water, which aids in rapid penetration and translocation within the plant.

The presence of functional groups containing $\mathrm{N}, \mathrm{O}$, and $\mathrm{S}$, as well as organic molecules, such as acids, alcohols, ketones, salts, amines, and thiols in agrochemicals, allow their connection to water via hydrogen bonds. Therefore, these agrochemicals become more soluble in water, but less soluble with the addition of halogen or alkyl groups (MACKAY et al., 2006).

As hydrogen ion concentrations increase (higher $\mathrm{pH}$ ), acid agrochemicals become more soluble while basic pesticides may become less soluble (OKUMURA; PEREIRA JUNIOR, 2011). The solubility of ionizable compounds (alcohols, amines, and acids) is strongly affected by changes in solution $\mathrm{pH}$ close to that of the dissociation constant (pKa). Ionic strength, salts, and minerals dissolved in water, produce moderate decreases in agrochemical solubility in water (PIERZYNSKI et al., 2005). In summary, the solubility of an organic compound in water is fundamentally important to environmental processes. This process affects the behavior of, transport to and fate of these compounds in the groundwater and thus increases their significance (CABRERA et al., 2008).

Solubility depends on compound's chemical structure, molecular size, functional groups, freedom of rotation, physical state, solvent $(\mathrm{pH}$, 
ionic strength, and polarity), and, of course, environmental conditions (temperature and pressure) (CAPEL, 1993; MARTINS et al., 2013).

Another measure of dilution is vapor pressure, which can be thought of as "air solubility" and expressed as mol m${ }^{-3}$, atm or Pa (MACKAY et al., 2006). Vapor pressure is dependent on the size and functional groups of an organic compound - the higher the pressure, the greater the likelihood an agrochemical will turn into a gas (BARRIGOSSI et al., 2005) reducing application efficiency. It should
PEREIRA, V. J. et al.

be noted that the greatest challenge and uncertainty in determining vapor pressure occurs in lowvolatility products, i.e., those with vapor pressure below 1.0 Pa $\left(\approx 10^{-5} \mathrm{~atm}\right)$ (MACKAY et al. 2006).

Molecules with vapor pressure between $10^{-4}$ and $10^{-11}$ atmospheres are considered semivolatile, while those with vapor pressure higher than $10^{-4}$ atmospheres are volatile. For convenience, vapor pressure is represented in logarithmic form (Table $3)$.

Table 3. Molecules classified by volatility and expressed as the log of vapor pressure (SILVA; FAY, 2004).

\begin{tabular}{cc}
\hline Volatility & Log of vapor pressure \\
\hline Very high & -3 \\
High & -4 to -3 \\
Moderate & -5 to -4 \\
Low & -6 to -5 \\
Very low & -7 to -6 \\
Extremely low & -7 \\
\hline
\end{tabular}

An understanding of vapor pressure sheds light on its significance to the application of agrochemicals. Specifically, vapor pressure indicates the tendency of a product to transpose from a liquid or solid to a gas (OLIVEIRA; BRIGHENTI, 2011). Similar to water solubility, vapor pressure helps determine the volatility of a substance in aqueous solution (BARRIGOSSI et al., 2005; OLIVEIRA; BRIGHENTI, 2011). This in turn helps predict whether molecules will enter the atmosphere at significant concentrations (BARRIGOSSI et al., 2005). Vapor pressure is strongly dependent, usually not linearly, on temperature. The volatility of a molecule depends on vapor pressure, which varies with climatic conditions (SILVA; FAY, 2004). This fact explains why losses due to volatility are greater in tropical climates than in temperate climates.

Volatilization from foliage is mainly determined by vapor pressure, which is in turn influenced by temperature. Temperatures on leaf surfaces can be much higher than air temperatures, particularly when solar radiation is high, leading to greater volatilization.

When an agrochemical is incorporated into the soil, losses from volatilization involve desorption and movement along the soil surface, and volatilization into the atmosphere (Table 4) (GEVAO et al., 2000). Therefore, incorporated agrochemicals volatilize at very low speeds that are dependent on the effective vapor pressure of the product within the soil and the surface speed of its movement.

Table 4. Adsorption behavior of agrochemicals in the soil (SILVA; FAY, 2004).

\begin{tabular}{ccc}
$\begin{array}{c}\text { Compounds with low vapor } \\
\text { pressure }\end{array}$ & Lesser transport & $\begin{array}{c}<\text { Atmospheric mobility } \\
<\text { Volatilization } \\
\text { > Persistence }\end{array}$ \\
\hline $\begin{array}{c}\text { Compounds with high vapor } \\
\text { pressure }\end{array}$ & Greater transport & $\begin{array}{c}\text { Atmospheric mobility } \\
>\text { Volatilization } \\
<\text { Persistence }\end{array}$ \\
\hline
\end{tabular}

The extent to which adsorption reduces agrochemical vapor pressure in the soil depends primarily on the nature and concentration of the agrochemical, moisture and soil properties (GEVAO et al., 2000). The type of soil or colloid, physicochemical nature and formulation of the agrochemicals, soil $\mathrm{pH}$, temperature and nature of exchangeable cations directly influence the adsorption / desorption of agrochemicals through the soil system (GEVAO et al., 2000).

Volatilization in moist soil is determined by soil moisture, vapor pressure, absorption, and product solubility (MINGUELA; CUNHA, 2011). Volatilization in dry soil depends on adsorption and 
vapor pressure. Ferrari et al. (2003) showed that volatilization can be as high as $22.6 \%$ for agrochemicals with vapor pressures between $5 \times 10^{-3}$ $\mathrm{Pa}$ and $5 \times 10^{-2} \mathrm{~Pa}$ under field conditions. According to Milhome et al. (2009), the agrochemicals azoxystrobin, imida-cloprido, nicosulfuron, paraquat, and thiamethoxam have low volatility and can therefore persist longer in the environment.

Volatilization in moist soil is described by Henry's Law constant $\left(\mathrm{K}_{\mathrm{h}}\right)$, which is calculated from vapor pressure, solubility, and molecular weight and indicates the degree of volatility of a chemical compound in a solution, usually expressed in $\mathrm{Pa} \mathrm{m}^{3}$ mol $^{-1}$ (MACKAY et al., 2006; CABRERA et al., 2008; OLIVEIRA; BRIGHENTI, 2011). Thus, the less water soluble, i.e., more non-polar, an agrochemical is, the more exposed it will be on the water surface and in the soil. The volatilization rates of non-polar pesticides will only decrease if soil organic matter is sufficiently high (SPADOTTO et al., 2010). Finally, moisture is unimportant for pesticides in gaseous form (GRAVEEL; TURKISH, 1994). In general, a plant protection chemical with a Henry's Law constant less than $10^{-1}$ has a low potential for volatilization from soil water while one with a constant higher than $10^{2}$ has a high potential for volatilization (MACKAY et al., 2006).

$\mathrm{K}_{\mathrm{h}}$, centered on volatility, also assists in toxicological analysis since high values suggest that inhalation would be the main route for poisoning (GRAVEEL; TURKISH, 1994; OLIVEIRA; BRIGHENTI, 2011).

There is also a close relationship between volatilization and application efficiency in that greater volatilization usually reduces application efficiency. Products with high vapor pressure levels may be lost as a gas before reaching the target, especially at high air temperatures (MINGUELA; CUNHA, 2011). Under non-ideal climatic and microclimatic conditions, pesticide losses may reach 80 to $90 \%$ a few days after application (SPADOTTO et al., 2010). Carter (2000) found herbicide losses due to volatilization as high as $90 \%$.

While there are several mathematical models to assess and predict the behavior and fate of pesticides in different environments, none of these accurately predicts volatilization. Therefore, these models require further development and improvement to accurately estimate volatilization (SPADOTTO et al., 2010).

\section{Physical-chemical properties related to bioaccumulation}

The n-octanol/water partition coefficient (Kow) characterizes hydrophobic molecules. Kow is the ratio at equilibrium between concentrations of a dissolved substance in a two phase system consisting of two immiscible liquids, n-octanol and water (SILVA; FERREIRA, 2003; BARRIGOSSI et al., 2005; MACKAY et al., 2006; MINGUELA; CUNHA, 2011). Thus, the ratio refers to the affinity a molecule has for the polar phase, represented by water, and the non-polar phase, represented by octanol, or, the lipophilicity of the molecule (OLIVEIRA; BRIGHENTI, 2011). Kow is usually given as a base 10 logarithm (ranging from -5 to 5 ) and is nondimensional (MACKAY et al., 2006). Lipophilic substances have high Kow values whereas hydrophilic substances have low values.

Kow is used to describe the transfer of a substance from an aquatic environment into an organism and the bioaccumulation potential of this substance (SILVA; FERRREIRA, 2003; SILVA; FAY, 2004; BARRIGOSSI et al., 2005; MACKAY et al., 2006; CABRERA et al., 2008; MINGUELA; CUNHA, 2011). The property is important for understanding the dynamics of absorption through the plant cuticle, which is essential for controlling diseases using systemic fungicides. Lipophilic products (high Kow) are able to penetrate the cuticle by simple diffusion at higher rates than hydrophilic products (BARRIGOSSI et al., 2005; QUEIROZ et al., 2008). It has also been demonstrated that product absorption by roots and subsequent translocation to the shoots is affected by compound lipophilicity (BARRIGOSSI et al., 2005). Phloem translocation also depends on the lipophilicity of a product.

Lipophilic compounds (e.g. nutrient solutions) accumulate in roots because of the affinity these compounds have for the solid, lipophilic components of the roots. Therefore, just as these compounds are more highly concentrated in octanol than in water, they are also more highly concentrated near solid root components than in the soil (BRIGGS et al., 1982; MACKAY et al., 2006; MINGUELA; CUNHA, 2011). Polar compounds (hydrophilic, low Kow) in the roots are mainly found in the intra or extracellular water phase and rarely with solid components. It is expected that the absorption of products applied to the soil will be less efficient than products applied in a nutrient solution due to adsorption (GEVAO et al., 2000).

Nonpolar or very lipophilic compounds are not translocated efficiently, despite abundant concentrations in the roots (BRIGGS et al., 1982; MINGUELA; CUNHA, 2011). The low permeability of cell membranes to polar compounds 
results in low translocation efficiency to leaves (BRIGGS et al., 1982; QUEIROZ et al., 2008; MILHOME et al., 2009). Thus, lipophilicity is an advantage for initial absorption, but proper translocation must occur through the aqueous phase.

Kow is also related to water solubility with soil/sediment adsorption coefficients, to aquatic life with bioconcentration factors and many other parameters that shed light on environmental behavior (CABRERA et al., 2008). Agrochemical accumulation and transport in living organisms are controlled by polarity, water solubility, affinity for fatty tissues, and potential binding to biological receptors.

Lipophyllic and nonpolar agrochemicals with high Kow values (> 10,000, >log 4) are strongly attached to lipids. Therefore, they have great potential for bioaccumulation in the fatty tissues of organisms such as soil invertebrates, some plant tissue, degraded organic materials, and organic matter (BARCELÓ; HENNION, 1997; BARRIGOSSI et al., 2005). Pyrethroid pesticides such as esfenvarelate, fenpropathrin, and lambdacyhalothrin have lipophilic properties, and organochlorine compounds such as endosulfan are considered bioaccumulative (MACKAY et al, 2006; MILHOME et al., 2009). Hydrophilic or polar pesticides with low Kow values $(<10)$ are not attracted to lipid materials and, clearly, are more soluble in water and have low soil / sediment absorption coefficients and low bioconcentration factors in aquatic life (MACKAY et al., 2006).

The accumulation potential of an organic compound is an important risk factor. When combined with degradation data, accumulation potential could be used to identify pesticides that can be transported via the food chain. Compounds with high bioaccumulation capacities usually have aliphatic and aromatic bonds, and due to their high stability, are relatively non-polar and originate nonpolar compounds (MACKAY et al., 2006). These non-polar compounds have low solubility in water and high solubility in fat and are the most common bioaccumulators in biota. Agrochemical bioaccumulation increases with lipophilicity, which is conveniently measured by the octanol-water partition coefficient (SILVA; FERRREIRA, 2003).

Since solubility is also related to Kow, bioaccumulation increases with decreasing solubility. When Kow is unknown, and only the water solubility of an agrochemical is known, then Kow can be estimated mathematically (BRIGGS, 1982).

\section{Physical-chemical properties related to persistance}

Almost every property of an agrochemical is targeted at understanding the behavior of the substance in the environment. Some measures are pure, others are associated with a characteristic such as adsorption and desorption, which are Kow derivatives. Water solubility, $\mathrm{pH}$, polarity, size, and configuration mainly determine a molecule's adsorption. The adsorption of a compound to the soil can be measured in several ways. The first of these is the ratio of substance concentration adsorbed by the soil to the concentration of the product in water. This measure is usually represented by $\mathrm{Kd}$ (Soil Colloid adsorption coefficient). The second measure is the ratio of the concentration of the product adsorbed by soil organic carbon to the concentration of the product in water. This measure is represented as Koc (the Organic Carbon-Water Partition Coefficient or the organic fraction) (SILVA; FAY, 2004; BARRIGOSSI et al., 2005; MACKAY et al., 2006; MINGUELA; CUNHA, 2011). These measures are of great importance in studies on agrochemical activity and agrochemical residues in the soil. They describe the movement or mobility potential of an agrochemical in soil, sediment, and groundwater (MACKAY et al., 2006) (Table 5).

Table 5. Classification of pesticides according to the strength of sorption by organic matter $\left(\mathrm{K}_{\mathrm{oc}}\right)(\mathrm{Gebler}$; Spadotto, 2004).

\begin{tabular}{cc}
\hline Sorption force & Sorption \\
\hline$>5000$ & Very strong \\
$600-4900$ & Strong \\
$100-599$ & Moderate \\
$0.5-99$ & Weak \\
\hline
\end{tabular}

The octanol-air partition coefficient $\left(\mathrm{K}_{\mathrm{OA}}\right)$ describes the partitioning of atmospheric chemicals with foliage. This ratio is also useful in describing the partitioning of aerosol particles with the soil. $\mathrm{K}_{\mathrm{OA}}$ has been applied in several situations that involve the partitioning of organic substances from the atmosphere into solid or liquid phases (MACKAY et al., 2006).

$\mathrm{K}_{\mathrm{OA}}$ is especially useful for solutes with high melting points (MACKAY et al., 2006). This 
index and others that involve partitioning between two systems by enthalpy vary with temperature. The partition coefficient, vapor pressure, $\mathrm{K}_{\mathrm{OW}}$ and $\mathrm{K}_{\mathrm{OA}}$ are sensitive to temperature variations due to large enthalpy changes that occur during transfer to the vapor phase (OLIVEIRA; BRIGHENTI, 2011).

Koc represents the tendency of a chemical to transfer from soil water to soil solids (organic matter) and has the advantage of being almost independent of soil type (MACKAY et al., 2006). Here, it is assumed that organic matter is fully responsible for the adsorption process (GEVAO et al., 2000). Regardless of the measure used, the higher $\mathrm{Kd}$ or Koc is, the greater the adsorption of the product to the soil. By themselves, these parameters cannot confidently express the actual contaminating potential of agrochemicals, but must be assessed together using risk analysis methods (MILHOME et al., 2009).

In practical terms, substances must be adsorbed by the soil to avoid leaching and contamination of the water table; however, this adsorption should not be so strong that it inhibits root absorption. The adsorption process determines chemical concentrations in the soil solution, which in turn affects the amount absorbed by plants and available for chemical and biological degradation, volatilization, and lixiviation (MINGUELA; CUNHA, 2011).

Products that are applied to clayey, organicrich soils should be applied at higher rates (within manufacturer specifications) due to the greater adsorption of the substance (GEVAO et al., 2000). Therefore, it can be inferred that sorption strongly impacts the distribution, bioavailability, and persistence of agrochemicals in the environment. Mobile agrochemicals may spread to deeper layers of the soil where microbial activity is often lower, with potentially significant implications for the persistence of agrochemical residues (SPADOTTO et al., 2010).

In general, retention is a key process affecting the fate of organic molecules in the soilwater environment (SPADOTTO et al., 2010). Retention can be caused by adsorption and absorption by the soil matrix and soil microorganisms. Adsorption is defined as the accumulation of a substance in soil-water and soilair interfaces; a process that is normally reversible and involves the attraction of a chemical to the surface of a solid particle that lasts for a period that is dependent on substance/surface affinity (GEVAO et al., 2000; MACKAY et al, 2006; OLIVEIRA; BRINGHENTI, 2011).
Retention processes are complex due to the heterogeneity of the soil and its interaction with biological, atmospheric, and aquatic systems. Adsorption-desorption is a dynamic process where molecules are continuously transferred between an aqueous solution and a solid surface. There are several mechanisms responsible for the sorption of any compound in the soil, including van der Waals force, Bridge $\mathrm{H}$, dipole-dipole interactions, and covalent bonds (GEVAO et al., 2000; OLIVEIRA; BRINGHENTI, 2011).

Cation exchange capacity and specific surface are colloid parameters that have been used to measure the adsorptive capacity of the soil. Organic matter is significant in sorption processes because it has a high specific surface area and cation exchange capacity. Physical and chemical characteristics of the soil are strongly influenced by colloidal constituents, which have high specific surfaces. All these factors affect soil $\mathrm{pH}$, which interacts with substance pH (GEVAO et al., 2000; CABRERA et al., 2008; OLIVEIRA; BRINGHENTI, 2011).

The $\mathrm{pH}$ of a substance affects all its physicochemical properties. In practical terms, $\mathrm{pH}$ affects corrosivity and thus leads farmers to choose the spraying equipment that best fits their needs (MINGUELA; CUNHA, 2011). Other applications refer to compatibility with other substances and the absorption of the product by biological cells (GOLDSMITH, 1977). By definition, $\mathrm{pH}$ is a decimal value with the opposite sign of hydrogen ion concentration. Other physicochemical properties can be predicted using $\mathrm{pH}$. For instance, solubility in aqueous medium and subsequent dissociation of a chemical substance in two or more chemical species can have $\mathrm{pH}$ values that differ from the original substance (MACKAY et al., 2006). Thus, a change in $\mathrm{pH}$ can imply a physical-chemical change (CUNHA et al., 2010). However, this example presents another important property called dissociation constant in an aqueous medium.

The dissociation of a chemical in water is of great importance in evaluating its behavior in the environment (BARRIGOSSI et al., 2005; MACKAY et al., 2006; MINGUELA; CUNHA, 2011) and may affect adsorption by soil and sediments and adsorption in plant cells (MACKAY et al., 2006; MINGUELA; CUNHA, 2011). Dissociation is the reversible decomposition of a chemical.

Knowing the dissociation constant of a chemical and the $\mathrm{pH}$ of the system in which the substance is located, makes it possible to estimate the extent to which the dissociated forms are 
present. It also provides information about the transfer of an aqueous solution to the atmosphere and soil (SILVA; FAY, 2004; MACKAY et al., 2006; CABRERA et al., 2008; MINGUELA; CUNHA, 2011). A substance that primarily exists in its dissociated form in an aquatic environment would probably not transfer to the air, but might be more strongly tied to the soil (MINGUELA; CUNHA, 2011).

Acidic and basic plant protection products can dissociate into ions in the aqueous soil solution at $\mathrm{pH}$ levels between 5 and 8 . This dissociation changes the behavior of these substances. Acid and base ionization constants, which represent the propensity of a compound to ionize, are therefore important for understanding the ionization conditions and processes that may lead to changes in product behavior (MACKAY et al., 2006) (MACKAY et al., 2006).

Thus, two ionization constants can be defined: acid and base. Minguela and Cunha (2011) did an extensive related review. The acid ionization constant ( $\mathrm{pKa}$ ) shows the tendency of a non-ionized acid to dissociate into an ionized compound and a hydrogen ion. Normally, the logarithm of the constant $\left(\mathrm{pKa}=-\log _{10}(\mathrm{Ka})\right)$ is used to facilitate interpretation. Thus, higher $\mathrm{pKa}$ values indicate weaker acids or greater potential to disassociate. The base ionization constant $(\mathrm{pKb})$ is defined similarly.

Even though the ionization constant has a strong impact on pesticide persistence in the soil, it also greatly affects agrochemicals absorption by plants. In general, leaf surfaces have predominantly negative charges and cation exchange properties. Therefore cation permeability of the cuticle is greater than that of anions. Furthermore nondissociated compounds penetrate more easily through the cuticle. Therefore, products with low $\mathrm{pKa}$ values are more dissociable (forming negative charges) and therefore have less adhesion to the cuticle and are absorbed more slowly (MINGUELA; CUNHA, 2011). Most current fungicides and insecticides are neutral compounds that do not ionize. This often can hinder the translocation of substances via phloem, which favors ionized compounds. Most fungicides and systemic insecticides translocate upward through the xylem. Hornsby et al. (1996) offer generalizations that assist in the interpretation of acid and base ionization constants of various plant protection substances (Table 6).

Table 6. Environmental consequences of phytosanitary ionization constants.

\begin{tabular}{|c|c|c|}
\hline pKa or pKb & Dominant phytosanitary & Environmental consequence \\
\hline $\mathrm{pKa}<3$ & Negative charge & $\begin{array}{l}\text { High mobility in soil unless complex chemical } \\
\text { compounds are formed, lower mobility under } \\
\text { acidic conditions, very soluble, low volatility. }\end{array}$ \\
\hline $\mathrm{pKa}>10$ & Neutral & $\begin{array}{l}\text { Behaves as a non-ionic material except in alkaline } \\
\text { conditions, lower mobility than anionic state, } \\
\text { probably lower solubility than anionic state } \\
\text { (negative charge), volatilization possible. }\end{array}$ \\
\hline pKa 3-10 & Calculate ratio $\mathrm{X}^{-} / \mathrm{XH}$ & $\begin{array}{l}\text { If } \mathrm{pH} \text { is close to } \mathrm{pKa} \text {, mobility, solubility, and } \\
\text { volatility will be influenced by } \mathrm{pH} \text {. }\end{array}$ \\
\hline $\mathrm{pKb}<4$ & Positive charge & $\begin{array}{l}\text { Low mobility, very soluble, low volatility, high } \\
\text { adsorption to the soil resulting in long half-life, but } \\
\text { with low biological activity. }\end{array}$ \\
\hline $\mathrm{pKb}>11$ & Neutral & $\begin{array}{l}\text { Behaves as a non-ionic material except under } \\
\text { acidic conditions, more mobile and less soluble } \\
\text { than in cationic state (positive charge), } \\
\text { volatilization possible. }\end{array}$ \\
\hline $\mathrm{pKb} 4-11$ & Calculate proportion $\mathrm{X}^{+} / \mathrm{X}(\mathrm{OH})$ & $\begin{array}{l}\text { If the value }(14-\mathrm{pH}) \text { is close to } \mathrm{pKb} \text {, mobility, } \\
\text { solubility, and volatility will be influenced by } \mathrm{pH} \text {. }\end{array}$ \\
\hline
\end{tabular}

Source: Hornsby et al. (1996).

Most organic acid compounds have pKa values between 4 and 5, many organic alcohols from 9 to 11 , and most amines and nitro compounds have $\mathrm{pKa}$ values between 10 and 12 . The presence of halogens in organic molecules lowers pK. For example, phenol with $\mathrm{pK}$ of 9.19 and pentachlorophenol of 4.75 . The lower the pKa value, the higher the degree of ionic dissociation, and the more soluble the substance is (MACKAY et al., 2006).

Many other types of organic functional groups do not have $\mathrm{pKa}$ values within the typical $\mathrm{pH}$ 
range of natural water. Therefore, these values are not within the normal environmental range of the molecules that possess them. Agrochemicals are strongly adsorbed when they have low solubility and an alkaline character. Molecular structure and functional groups must be understood because they determine the partition intensity between water and solids in the soil. Agrochemicals that ionize in aqueous solution and produce positively charged ions, such as the cation herbicide paraquat $(\mathrm{pKa}=$ 11), behave differently in the soil system than those that produce negatively charged ions, such as 2,4-D herbicide or the basic herbicide ametryn (MACKAY et al., 2006).

Herbicides, for example, can be considered acids. The molecular (neutral) forms of these herbicides can donate protons, forming negatively charged ions. The higher the pKa value an herbicide has, the weaker its acid strength and the lower its chance of becoming anionic. Basic herbicides are those whose neutral (molecular) forms can receive protons and form positively charged ions. Since it is common to find similar $\mathrm{pKa}$ values for acidic and basic herbicides, it must be considered that the protonated chemical species is an acid conjugated from a basic substance. Hence, basic products use the same $\mathrm{pKa}$ notation, where the higher the $\mathrm{pKb}$ value of a product (or lower $\mathrm{pKa}$ value), the weaker the basic strength, or the lower the chance the herbicide will become cationic. Products that neither donate nor receive protons in solution are considered non-ionic and remain in molecular form (OLIVEIRA; BRIGHENTI, 2011).

\section{Physical-chemical properties related to degradation}

Molecules in the environment are subject to numerous reactions that lead to the degradation of active ingredients. These reactions include hydrolysis, oxidation, biological degradation, and photodegradation. Photodegradation is the most important of these for agrochemicals. Molecular compound identification can indicate the wavelength at which a substance is susceptible to photodegradation (OLIVEIRA; BRIGHENTI, 2011). In general, fungicides are subject to photolysis because they are made of very fine particles of high specific surface. These can easily dissolve in a film of water on the leaf surface where they are exposed to sunlight (GARCIA, 1999).

Photolysis is a reaction that breaks down molecules via the energy available in photons of various wavelengths (290 to $400 \mathrm{~nm}$ ) (SILVA; FAY, 2004; MACKAY et al., 2006; MINGUELA; CUNHA, 2011). Photolysis can be a direct process in which a substance is transformed by absorbing light energy, or an indirect process in which other substances absorb energy, transform, and then alter the primary substance (MINGUELA; CUNHA, 2011).

The photolysis or photodegradation or photochemical degradation of a substance can be measured by half-life (MACKAY et al., 2006). The process is caused by the absorption of light, especially ultraviolet which is more destructive, (RADOSEVICH et al., 1997) resulting in the excitation of electrons and consequent breakdown of certain molecular bonds (OLIVEIRA; BRIGHENTI, 2011). Therefore, the photodegradation of certain molecular bonds occurs only if there is light (specific to each substance) that can excite electrons.

Products that undergo this kind of degradation must be incorporated into the soil to avoid losses and increase efficiency. Adjuvants can also be used to minimize losses. The color of an agrochemical can interfere in its predisposition to photodegradation. Colored agrochemicals such as trifluralin, oryzalin, treflan, and surflan herbicides are less apt to resist photodegradation (SPADOTTO et al., 2010).

Hydrolysis is another degradation process that introduces a hydroxyl group to the initial molecule. The resulting substance is usually more susceptible to possible biodegradation and photolysis. The hydroxyl group also makes the compound soluble in water and therefore reduces the potential for bioconcentration. In other words, the resulting substance is more easily degraded, less persistent, and less toxic than the original compound (OLIVEIRA; BRIGHENTI, 2011).

This transformation of the pesticide can even be used in some cases to activate the substance. Here, the protective mechanism would function within a given soil moisture range for optimal effect. This is possible because hydrolysis does not inactivate the product in one step, but requires many steps that can lead to very long persistence (SPADOTTO et al., 2010).

The longevity of a molecule, either in soil or in solution, is usually expressed in half-lives $\left(\mathrm{T}_{1 / 2}\right)$ of the parent compound. A half-life is the time required for half the concentration of the pesticide to disappear, irrespective of the initial soil concentration (SILVA; FAY, 2004; MACKAY et al., 2006; MINGUELA; CUNHA, 2011). Thus, if the half-life of the product is 30 days, then half will remain in the environment after 30 days, a quarter after 60 day, an eighth after 90 days, and so on (BARRIGOSSI et al., 2005). The half-life of an 
agrochemical is therefore a measure of its persistence in the soil. This property is very important for products applied to the soil and for predictions of possible environmental contamination (GEVAO et al., 2000; BARRIGOSSI et al., 2005; MACKAY et al., 2006; MINGUELA; CUNHA, 2011).

The degradability of agrochemicals, usually expressed as half-life (GEVAO et al., 2000; BARRIGOSSI et al., 2005; MACKAY et al., 2006; CABRERA et al., 2008; MINGUELA; CUNHA, 2011), varies significantly and can be measured in days (organophosphates), months (triazine herbicides) or years (DDT and dieldrim) (Table 7). However, there is no single value for the half-life of agrochemicals. Moreover, the determination of these values is strongly influenced by environmental conditions (soil, location, climate, biological activity). Thus, it is impossible to record a reliable single half-life. The best approach is to assume average environmental conditions and suggest a semi-quantitative classification of half-lives in groups or intervals. Half-life is calculated using the natural logarithm of 2 divided by reaction time. Thus, a chemical that biodegrades at a constant rate of $0.0014 \mathrm{~h}^{-1}$ has a half-life of 495 hours. Usually, reaction rates in water are one to two orders of magnitude slower than in air (MACKAY et al., 2006).

Table 7. Half-life classes (MACKAY et al., 2006).

\begin{tabular}{cll}
\hline Class & Average $\mathbf{T}_{\mathbf{1 / 2}}$ & Maximum time (hours) \\
\hline 1 & $5<10$ hours & - \\
2 & $17(\approx 1$ day $)$ & $10-30$ \\
3 & $55(\approx 2$ days $)$ & $30-100$ \\
4 & $170(\approx 1$ week $)$ & $100-300$ \\
5 & $550(\approx 3$ weeks $)$ & $300-1000$ \\
6 & $1700(\approx 2$ months $)$ & $1000-3000$ \\
7 & $5500(\approx 8$ months $)$ & $3000-10000$ \\
8 & $17000(\approx 2$ years $)$ & $10000-30000$ \\
9 & $55000(\approx 6$ years $)$ & $30000-100000$ \\
10 & $>11$ years & $>100000$ \\
\hline
\end{tabular}

Most data on phytosanitary's half-life have been determined in Europe and in the United States and therefore are not directly applicable in tropical countries (DORES; DE-LAMONICA-FREIRE, 1999). Wauchope et al. (1992) found that data collected in temperate zones varied as much as three times. Thus, half-life should be determined under normal conditions in the region where the organic compound is used.

Half-lives are important for understanding the potential environmental impact of agrochemicals. For example, if a highly toxic pesticide reaches a lake and its photolysis is rapid (suggesting low $\mathrm{T}_{1 / 2}$ ), the environmental consequences may be minimal if the photolysis's products are nontoxic. However, in the same situation, a moderately toxic pesticide with a low photolysis rate (indicating high $\mathrm{T}_{1 / 2}$ ) could have a significant environmental impact (BARRIGOSSI et al., 2005). This scenario may also be used to determine environmental effects related to the volatilization, leaching, and degradation characteristics of various chemical compounds (SPADOTTO et al., 2010).

Half-lives are difficult to measure in laboratory given wide variations in climate and soil conditions. Thus, half-lives can only be used as estimates and for comparison between different products (MINGUELA; CUNHA, 2011). This concept is useful for comparing the relative persistence of various pesticides (MACKAY et al., 2006). In general, the half-life of phytosanitary substances should last long enough to allow greater control; however, not so long that it affects subsequent crops. From the standpoint of application technology, these data are frequently used to model pesticide fate (SPADOTTO et al., 2010).

From an ecological point of view, agrochemical contamination of surface water is determined using the Goss criterion, which considers the half-life of a compound in the soil (soil $\mathrm{T}_{1 / 2}$ ), solubility in water at $25^{\circ} \mathrm{C}$, and the adsorption constant by soil organic matter (Koc) (MACKAY et al., 2006; CABRERA et al., 2008). According to this criterion, pesticides are grouped according to transport in suspended sediment (High Potential for Surface Water Transport - HPSWT and Low Potential for Surface Water Transport LPSWT) and by transport when dissolved in water (High Potential for Dissolved surface Water Transport - HPDWT and Low Potential for 
Dissolved surface Water Transport - LPDWT). The values for each parameter of these groups are: HPSWT $-T_{1 / 2}$ in soil $\geq 40$ days and $K o c=1,000 \mathrm{~cm}^{3}$ $\mathrm{g}^{-1}$, or $\mathrm{T}_{1 / 2}$ in soil $\geq 40$ days, Koc $\geq 500 \mathrm{~cm}^{3} \mathrm{~g}^{-1}$, and solubility in water $\leq 0.5 \mathrm{mg} \mathrm{L}^{-1}$; LPSWT $-\mathrm{T}_{1 / 2}$ in soil $<1$ day, or $T_{1 / 2}$ in soil $\leq 40$ days, Koc $\leq 500$ $\mathrm{cm}^{3} \mathrm{~g}^{-1}$, and solubility $\geq 0.5 \mathrm{mg} \mathrm{L}^{-1}$, or $\mathrm{T}_{1 / 2}$ in soil $\leq$ 2 days and Koc $\leq 500 \mathrm{~cm}^{3} \mathrm{~g}^{-1}$, or $\mathrm{T}_{1 / 2}$ in soil $\leq 4$ days, Koc $\leq 900 \mathrm{~cm}^{3} \mathrm{~g}^{-1}$, and solubility in water $\geq$ $0.5 \mathrm{mg} \mathrm{L}^{-1}$, or $\mathrm{T}_{1 / 2}$ in soil $\leq 40$ days and Koc $\leq 900$ $\mathrm{cm}^{3} \mathrm{~g}^{-1}$, and solubility in water $\geq 2 \mathrm{mg} \mathrm{L}^{-1}$; HPDWT $-\mathrm{T}_{1 / 2}$ in soil $>35$ days, Koc $<1,000,000 \mathrm{~cm}^{3} \mathrm{~g}^{-1}$, and solubility $>1 \mathrm{mg} \mathrm{L}^{-1}$, or $\mathrm{T}_{1 / 2}$ in soil $>35$ days, Koc $<700 \mathrm{~cm}^{3} \mathrm{~g}^{-1}$, and solubility in water between 10 and $100 \mathrm{mg} \mathrm{L}^{-1}$; LPDWT - Koc $>1,000,000 \mathrm{~cm}^{3}$ $\mathrm{g}^{-1}$, or $\mathrm{T}_{1 / 2}$ in soil $<1$ day and Koc $<100 \mathrm{~cm}^{3} \mathrm{~g}^{-1}$, or $\mathrm{T}_{1 / 2}$ in soil $<35$ days and solubility in water $<0.5$ mg L ${ }^{-1}$ (CABRERA et al., 2008). Compounds that do not fall into any of these groups are considered to have an average potential to contaminate surface waters via transport while dissolved in water (APDWT) or suspended in sediment (APSWT) (CABRERA et al., 2008).

Another approach is to assess leaching potential using the GUS index (Groundwater Ubiquity Score), which is calculated using soil $\mathrm{T}_{1 / 2}$ and pesticide Koc (Cabrera et al., 2008): GUS = $\left(\log\right.$ soil $\left.\mathrm{T}_{1 / 2}\right) \times(4-\log \mathrm{Koc})$. This calculation is classified into three categories: pesticides that are not leached (NL) GUS $<1.8$, pesticides in transition (TL) $1.8<$ GUS < 2.8, and pesticides that are probably leached (PL) GUS > 2.8 (MACKAY et al., 2006; CABRERA et al., 2008).

\section{Physical and chemical properties related to interactions with leaf surfaces}

The tenacity of an agrochemical can be determined from various characteristics (MINGUELA; CUNHA, 2011). Tenacity is essentially resistance to weather. If a chemical adheres strongly to the leaf surface (tenacity), the substance's effect can last for long time (persistence). A good fungicide, for example, should not degrade by hydrolysis, photochemical reactions, volatilization or sublimation, and especially should not easily wash off with water. This characteristic is the most important for contact fungicides that must persist for long periods on treated surfaces without being removed or degraded (MINGUELA; CUNHA, 2011).

Another important agrochemical property that affects application is surface tension, which consists of forces among non-miscible liquids that keep them from mixing. In a liquid of polarized molecules, such as water, attraction is significant and exerted in all directions. Discontinuity of the liquid phase on the surface of the liquid increases this attraction and generates surface tension. The wettability of a plant leaf, which is a desirable quality in applications that rely on leaf contact, depends on constituents of the leaf and characteristics of the pesticide (KISSMANN, 1998). Good wettability occurs when the attraction between the leaf surface and water is greater than the surface tension of the liquid. Thus the surface tension of the agrochemical should not be very high. The quality of the water used and the presence of adjuvants are also of great influence.

The retention and adhesion of the spray to the leaf surface is a consequence of good wettability. This occurs due to the contact angle between the spray droplet and the target, which is in turn influenced by the presence of surfactants in the spray solution (TANG; DONG, 2008). Yu et al. (2009) and $\mathrm{Xu}$ et al. (2010) reported that surfactants in the spray solution increase the wettability of spray droplets on the target. Hilz and Vermeer (2013) also showed that surface tension affects the size of spray droplets.

Surfactants in spray solutions help form liquid films on the leaf surface due to droplet coalescence (MONTORIO et al., 2005). The surface tension of droplets and their interaction with the target surface influence not only wettability, but also the adsorption process that is essential for effective applications.

Taylor (2011) studied the wettability of plant surfaces and showed that spray retention on the target is very important for the biological effectiveness of plant protection products, mainly on surfaces where retention is difficult. According to the author, if the properties of spray droplets are not optimized, much of the spray will be lost, thus underlining the importance of knowing the surface tension of a spray solution.

\section{Final considerations}

Experiments in laboratory and in the field provide an understanding of the characteristics that will influence the behavior of a pesticide in the environment and help improve application efficiency, decreasing losses and ensuring effective diseases and pests' control. In practical terms, the more effective an application is, the less damage there will be to the agroecosystem and to the different trophic levels of the biosphere. This leads to reductions in environmental impacts, needed to optimize soil use and consequent economic and social development. To discuss the physicochemical properties of agrochemicals is to discuss agricultural 
sustainability, nowadays addressed as green agriculture. Therefore, initiatives that unite the fragmented information available in scientific literature or inspire debates on this topic are desirable and necessary.

There are few Brazilian studies on pesticides' properties, which are intrinsic to each molecule. Inferences are mainly made regarding studies on adjuvants. Furthermore, these studies do not consider environmental conditions or "tank mixes", which are common practices done by farmers. This knowledge gap needs to be filled so that, as in Europe, Brazil can establish a Constitution related to agrochemicals that includes, for example, threshold toxicity and contamination of water and animals.

It is only possible to infer the behavior of agrochemical molecules in the environment and predict or minimize environmental damage by understanding the physical-chemical properties of these molecules. Studies should consider more than one property under distinct environmental conditions. For instance, the more mobile and persistent a molecule is, the greater its potential for seepage and leaching and hence the greater its potential for contaminating ground, surface, and subsurface water. Furthermore, these molecules become more environmentally aggressive when they have a high potential for bioaccumulation and degrade slowly in the environment.

Besides understanding the physicalchemical properties of pesticides, a correct handling of these substances is important to ensure a safe application. Studies on this topic also promote rural development without jeopardizing the environment. The present study shows the lack of information on the physicochemical properties of agrochemical spray solutions and on the factors influencing them, probably due to complexities inherent in these substances and their mixtures.

\section{ACKNOWLEDGMENTS}

To CAPES (Coordenação de Aperfeiçoamento de Pessoal de Nível Superior) for the financial support given to the third and fourth authors and to the Programa de Pós-Graduação em Ciência, Inovação e Tecnologia para a Amazônia (CITA-UFAC) for the support given currently to the fourth author.

RESUMO: Quais são, como e por que estudar as propriedades moleculares de agrotóxicos? Quais seus impactos no agroecossistema? Como associá-las à tecnologia de aplicação? Estes questionamentos são decorrentes da escassez literária sobre o tema e são a base argumentativa desta revisão. De maneira geral, o conhecimento das características físico-químicas dos agrotóxicos possibilita aumentar a eficiência e reduzir as perdas dos produtos no ato da aplicação, o que se associa às predições de sucesso desta aplicação e, consequentemente, à manutenção da integridade ambiental. Estes aspectos ressaltam a importância do tema, há muito discutido na Europa. No Brasil, são poucas as pesquisas relacionadas às propriedades físico-químicas dos agrotóxicos, intrínsecas a cada molécula, e praticamente inexistentes as discussões sobre seus impactos. Por isto, esta revisão visa elucidar conceitos, aplicações e interações das propriedades físico-químicas de agrotóxicos com o ambiente. Indiscutivelmente, os segredos comerciais relacionados às moléculas são o grande arcabouço da indústria de agrotóxico, o que certamente restringe publicações científicas na área. Contudo, sabe-se que estas propriedades estão associadas à mobilidade dos produtos no solo, sua dissociação em água, bioacumulação, persistência e durabilidade no ambiente e no alvo. Em suma, quanto mais móvel e persistente uma molécula, maior seu potencial de percolação e lixiviação, consequentemente, maior a sua periculosidade de contaminação de águas subterrâneas, subsuperficiais e superficiais. Esta molécula torna-se mais agressiva ambientalmente se possuir elevado potencial de bioacumulação e baixa degradação no meio. Cabe salientar que o correto manejo dos agrotóxicos depende não somente do conhecimento de suas propriedades moleculares, mas de uma aplicação segura. Estes aspectos são fundamentais na promoção do desenvolvimento rural sem entraves ambientais.

PALAVRAS-CHAVE: Defensivos agrícolas. Propriedades moleculares. Tecnologia de aplicação. Sustentabilidade.

\section{REFERENCES}

ALTENBURGER, R.; BOEDEKER, W.; FAUST, M.; GRIMME, L. H. Comparative hazard identification for pesticides: interrelations between physico-chemical properties, tonnages, and occurrence in surface waters. Science of the Total Environment, v. 134, p. 1633-1654, 1993. http://dx.doi.org/10.1016/S00489697(05)80166-4 
BARCELÓ, D.; HENNION, M. C. Trace determination of pesticides and their degradation products in water: techniques and instrumentation in analytical chemistry. v. 19. New York: Elsevier, 1997. 556 p.

BARRIGOSSI, J. A. F.; LANNA, A. C.; FERREIRA, E. Inseticidas registrados para a cultura do arroz e análise de parâmetros indicadores de seu comportamento no ambiente. Santo Antônio de Goiás: Embrapa Arroz e Feijão, 2005. 4 p. (Embrapa Arroz e Feijão. Circular Técnica, 74).

BRIGGS, G. G.; BROMILOW, R. H.; EVANS, A. A. Relationships between lipophilicity and root uptake and translocation of non-ionised chemicals by barley. Pesticide science, v. 13, n. 5, p. 495-504, 1982.

http://dx.doi.org/10.1002/ps.2780130506

CABRERA, L.; COSTA, F. P.; PRIMEL, E. G. Estimativa de risco de contaminação das águas por pesticidas na região sul do Estado do RS. Química Nova, v. 31, n. 8, p. 1982-1986, 2008.

http://dx.doi.org/10.1590/S0100-40422008000800012

CAPEL, P. D. Organic chemical concepts. In: ALLEY, W. M. (Ed.). Regional ground-water quality. New York: Van Nostrand Reinhold, 1993. p.155-180.

CARTER, A. D. Herbicide movement in soils: principles, pathways and processes. Weed Research, v. 40, p. 113-122, 2000. http://dx.doi.org/10.1046/j.1365-3180.2000.00157.x

CUNHA, J. P. A. R.; ALVES, G. S.; REIS, E. F. Efeito da temperatura nas características físico-químicas de soluções aquosas com adjuvantes de uso agrícola. Planta Daninha, v. 28, n. 3, p. 665-672, 2010.

http://dx.doi.org/10.1590/S0100-83582010000300024

DIAS, A. C. R. Comportamento no ambiente e propriedades físico-químicas de pesticidas. 30 set. 2010. Palestra.

DORES, E. F. G. C.; DE-LAMONICA-FREIRE, E. M. Contaminação do ambiente aquático por agrotóxicos: vias de contaminação e dinâmica dos agrotóxicos no ambiente aquático. Pesticidas: Revista de Ecotoxicologia e Meio Ambiente, v. 9, n. 1, p. 1-18, 1999.

FARM CHEMICALS INTERNATIONAL. Crop Protection Dictionary. Disponível em: http://www.farmchemicalsinternational.com/cropprotection/cpd/?op=cpdproductdetail\&pid=203900. Acesso em: 31 mar. 2012.

FERRARI, F.; TREVISAN, M.; CAPRI, E. Predicting and measuring environmental concentration of pesticides in air after soil application. Journal of Environmental Quality, v. 32, p. 1623-1633, 2003. http://dx.doi.org/10.2134/jeq2003.1623

GARCIA, A. Fungicidas I: utilização no controle químico de doenças e sua ação contra os fitopatógenos. Porto Velho: EMBRAPA-CPAF Rondônia, 1999. 32 p.

GEBLER, L.; BELLO FIALHO, F. Introduzindo critérios de risco em modelos de contaminação pontual para locais de carga de agrotóxicos. Pesticidas: Revista de Ecotoxicologia e Meio Ambiente, v. 21, p. 85-94, 2011.

GEBLER, L.; PELIZZA, T. R.; ALMEIDA, D. L. Variáveis ambientais e toxicológicas de agroquímicos utilizados na Produção Integrada de Maçãs (PIM) visando modelagem matemática. Revista de Ciências Agroveterinárias, v. 5, n. 2, p. 169-184, 2006.

GEBLER, L.; SPADOTTO, C. A. Comportamento ambiental dos herbicidas. In: VARGAS, L.; ROMAN, E. S. (Ed.). Manual de manejo e controle de plantas daninhas. Bento Gonçalves: Embrapa Uva e Vinho, 2004. p. 57-87. 
GEVAO, B.; SEMPLE, K. T.; JONES, K. C. Bound pesticide residues in soils: a review. Environmental pollution, v. 108, n. 1, p. 3-14, 2000. http://dx.doi.org/10.1016/S0269-7491(99)00197-9

GOLDSMITH, M. H. M. The polar transport of auxin. Annual Review of Plant Physiology, v. 28, n. 1, p. 439-478, 1977. http://dx.doi.org/10.1146/annurev.pp.28.060177.002255

GRAVEEL, J. G.; TURCO, R. F. Factors affecting mobility of pesticides in soil. In: Intensive course on the activity, selectivity, behavior and fate of herbicides in plants and soils. West Lafayette, Indiana, USA: Purdue Universitty, Departments of Horticulture, Agronomy, Botany, Plant Pathology, Foresty, and Natural Resources, 1994. p. 464-507.

HILZ, E.; VERMEER, A. W. P. Spray drift review: The extent to which a formulation can contribute to spray drift reduction. Crop Protection, v. 44, n. 1, p. 75-83, 2013. http://dx.doi.org/10.1016/j.cropro.2012.10.020

HORNSBY, A. G.; WAUCHOPE, R. D.; HERNER, A. E. Pesticide properties in the environment. New York: Springer-Verlag, 1996. 227 p. http://dx.doi.org/10.1007/978-1-4612-2316-0

IBAMA - Instituto Brasileiro do Meio Ambiente e dos Recursos Naturais Renováveis. Portaria no 6. 17 de maio de 2012. DOU 23/05/2012, Brasília, 2012.

KISSMANN, K. G. Adjuvantes para caldas de produtos fitossanitários. In: GUEDES, J. V. C.; DORNELLES, S. B. (Ed.). Tecnologia e segurança na aplicação de agrotóxicos: novas tecnologias. Santa Maria: Departamento de Defesa Fitossanitária; Sociedade de Agronomia de Santa Maria, 1998. p. 39-51.

MACKAY, D.; SHIU, W. Y.; MA, K. C.; LEE, S. C. Handbook of physical-chemical properties and environmental fate for organic chemicals. 2. ed. v. 1. Boca Raton: CRC press, 2006. 925 p.

MARTINS, C. R.; LOPES, W. A.; ANDRADE, J. B. Solubilidade das substâncias orgânicas. Química Nova, v. 36, n. 8, p. 1248-1255, 2013. http://dx.doi.org/10.1590/S0100-40422013000800026

MILHOME, M. A. L.; SOUSA, D. D. O. B. D.; LIMA, F. D. A. F.; NASCIMENTO, R. D. Avaliação do potencial de contaminação de águas superficiais e subterrâneas por pesticidas aplicados na agricultura do Baixo Jaguaribe, CE. Engenharia Sanitária e Ambiental, v. 14, n. 3, p. 363-372, 2009.

http://dx.doi.org/10.1590/S1413-41522009000300010

MINGUELA, J. V.; CUNHA, J. P. A. R. Manual de aplicação de produtos fitossanitários. Viçosa: Aprenda Fácil Editora, 2011. 588 p.

MONTÓRIO, G. A.; VELINI, E. D.; MACIEL, C. D.; MONTÓRIO, T. Eficiência dos surfactantes de uso agrícola na redução da tensão superficial. Revista Brasileira de Herbicidas, v. 4, n. 2, p. 8-22, 2005. http://dx.doi.org/10.7824/rbh.v4i2.21

OKUMURA, M. H.; PEREIRA JÚNIOR, H. R. J. Recuperação de áreas degradadas pela agricultura convencional, com auxílio da agricultura orgânica. Complexus, n. 4, p. 145-160, 2011.

OLIVEIRA, M. F.; BRIGHENTI, A. M. Comportamento dos herbicidas no ambiente In: OLIVEIRA J. R.; CONSTANTIN, J.; INOUE, M. H. (Ed.). Biologia e Manejo de Plantas Daninhas. Curitiba-PR: Omnipax, 2011. p. 263-304.

PAULA, J. M.; VARGAS, L.; AGOSTINETTO, D.; NOHATTO, M. A. Manejo de Conyza bonariensis resistente ao herbicida glyphosate. Planta Daninha, v. 29, n. 1, p. 217-227, 2011.

http://dx.doi.org/10.1590/S0100-83582011000100024

PIERZYNSKI, G. M; VANCE, G. F.; SIMS, J. T. Soils and environmental quality. 3. ed. Boca Raton: CRC Press, 2005. 584 p. 
PROKOP, M.; KEJKLÍCEK, R. Effect of adjuvants on spray droplet size of water. Journal of Agricultural Engineering Research, v. 48, n. 4, p. 144-148, 2002.

QUEIROZ, A. A.; MARTINS, J. A. S.; CUNHA, J. P. A. R. Adjuvantes e qualidade da água na aplicação de agrotóxicos. Bioscience Journal, v. 24, n. 4, p. 8-19, 2008.

RADOSEVICH, S. R.; HOLT, J.; GHERSA, C. Weed ecology. New York: John Wiley \& Sons, 1997. 589 p.

SHEN, L.; WANIA, F. Compilation, evaluation, and selection of physical-chemical property data for organochlorine pesticides. Journal of Chemical \& Engineering datas, v. 50, n. 3, p. 742-768, 2005.

SILVA, C. M. M. S.; FAY, E. F. Agrotóxicos: aspectos gerais. In: SILVA, C. M. M. S.; FAY, E. F. (Ed.). Agrotóxicos e Ambiente. Brasília: Embrapa Informação Tecnológica, 2004. p. 17-73.

SILVA, L. R.; FERREIRA, M. M. C. Estudo do coeficiente de partição octanol-água de bifenilas policloradas (PCBs) utilizando parâmetros topológicos. Química Nova, v. 26, n. 3, p. 312-318, 2003.

http://dx.doi.org/10.1590/S0100-40422003000300005

SPADOTTO, C. A.; SCORZA JUNIOR, R. P.; DORES, E. D. C.; GEBLER, L.; MORAES, D. D. C. Fundamentos e aplicações da modelagem ambiental de agrotóxicos. Campinas: Embrapa Monitoramento por Satélite, 2010.46 p.

TANG, X.; DONG, J.; LI, X. A comparison of spreading behaviors of Silwet 1-77 on dry and wet lotus leaves. Jounal of Colloid and Interface Science, v. 325, n. 1, p. 223-227, 2008.

http://dx.doi.org/10.1016/j.jcis.2008.05.055

TAYLOR, P. The wetting of leaf surfaces. Current Opinion in Colloid \& Interface Science, v. 16, n. 4, p. 326-334, 2011. http://dx.doi.org/10.1016/j.cocis.2010.12.003

WAUCHOPE, R. D.; BUTTLER, T. M.; HORNSBY, A. G.; AUGUSTIJN-BECKERS, P. W. M.; BURT, J. P. The SCS/ARS/CES pesticides properties database for environmental decision-making. Reviews of Environmental Contamination and Toxicology, v. 123, p. 1-35, 1992. http://dx.doi.org/10.1007/978-14612-2862-2_1

XU, L.; ZHU, H.; OZKAN, H. E.; THISTLE, H. W. Evaporation rate and development of wetted area of water droplets with and without surfactant at different locations on 357 waxy leaf surfaces. Biosystems Engineering, v. 106, n. 1, p. 58-67, 2010. http://dx.doi.org/10.1016/j.biosystemseng.2010.02.004

YU, Y.; ZHU, H.; OZKAN, H. E.; DERKSEN, R. C.; KRAUSE, C. R. Evaporation and deposition coverage area of droplets containing insecticides and sprays additives on hydrophilic, hydrophobic, and crabapple leaf surfaces. Transactions of the ASABE, v. 52, n. 1, p. 39-49, 2009. http://dx.doi.org/10.13031/2013.25939 